\title{
MALE ANTIFERTILITY COMPOUNDS: U-5897 AS A RAT CHEMOSTERILANT
}

\author{
R. J. ERICSSON \\ Fertility Research, The Upjohn Company, \\ Kalamazoo, Michigan 49001
}

(Received 14th May 1969)

\begin{abstract}
Summary. U-5897 (3--hloro-1,2-propanediol) is an effective male rat chemosterilant. Sterility results from a lesion in the initial segment of the caput epididymidis. Minimal amounts required to develop lesions consistently are daily oral doses of $35 \mathrm{mg} / \mathrm{kg}$ body weight or one $45 \mathrm{mg} / \mathrm{kg}$ dose. The immediate consequences of the lesion are sperm blockage in ductuli efferentes and testicular swelling. Fluid accumulation in the testis causes pressure degeneration of the germinal epithelium. Testicular damage does not include morphological or functional (coitus, vaginal plugs, limited spermatogenesis) impairment of Leydig cells. U-5897 is thought to cause local ischaemia, with resultant epithelial desquamation which blocks the caput epididymidis. This is followed by the formation of spermatocoeles, sperm granulomata, and fibrosis. Males madesterile with such a lesion had normal libido with seventy-one matings out of seventy-seven opportunities $(92 \%)$ over a 64-day period. Adult rats given a single oral dose of 90 to $100 \mathrm{mg} / \mathrm{kg}$ of U-5897 still had lesions blocking sperm passage when killed at 3-month intervals over at least 12 months. Although sterile, they continued to mate and enjoyed good general health. Testes were small due to many non-functional seminiferous tubules but spermatogenesis continued in a few tubules. Compound acceptance and potency, route and length of administration, and biological effectiveness make U-5897 and the concept of a male chemosterilant worthy of practical consideration.
\end{abstract}

\section{INTRODUCTION}

Sterilization of male insects, as shown by mathematical models, is ultimately more efficient than killing as a method of population control (Knipling, 1959). Chemosterilants have been suggested as an effective method to control vertebrate populations. This premise is based on the concept that sterile individuals in a population exert much greater control than if the same number of fertile individuals were removed (Howard, 1967), since the sterile individuals continue to compete for territory, food, social order and sexual partners. A male rat mates with females within this social framework; if made sterile, with normal libido, he will exert a stabilizing influence on the local population. A 
cadre of sterile males expresses population control in an exacting manner. Females mated with sterile males exhibit pseudopregnancy which limits coitus with fertile males and, with time, their reproductive capacity. Of unknown importance are the problematical ecological changes brought about by limiting the number of offspring.

A new approach to rat control is warranted in that mankind has an inadequate record in controlling this rodent (Clinton, 1968), and the use of the universal rodenticide, Warfarin, has, like DDT in other species, produced in several European countries a strain of Rattus norvegicus with considerable genetic tolerance to the drug (Bentley, 1967; Pool, O'Reilly, Schneiderman \& Alexander, 1968). A suitable chemosterilant should have the following characteristics: (i) single-dose effectiveness; (ii) activity by mouth in food or water; (iii) relative non-toxicity to other wild life, domestic animals, or man; (iv) drug stability in a harsh environment; (v) minimal cost; and, of great importance, (vi) acceptance of drug in bait.

A class of compounds which encompasses many of the needed chemosterilant requirements is now available for experimentation against the male rat. The compounds-chlorohydrins-were found to have antifertility activity in the male rat (Ericsson \& Youngdale, 1970). Later, it was learned that five times the minimal effective dose of two chlorohydrins, U-5897 and U-15,646, produced lesions in the caput epididymidis (Ericsson \& Baker, 1970). The significance of this finding was more fully realized when other species failed to develop lesions (Kirton, Ericsson, Ray \& Forbes, 1970) even though each species had comparable percentages and routes of drug elimination (Kirton, Ericsson, Miller, Cornette, Forbes \& Duncan, 1969). U-5897 (3-chloro-1,2propanediol) was selected for extensive testing with the hope that success would provide a new compound to test for rat control. Included in this report are a multiplicity of studies which together explain the worth of U-5897 as a male rat chemosterilant.

\section{MATERIALS AND METHODS}

Spartan and Upjohn rats ( 300 to $500 \mathrm{~g}$ ) were used throughout and housed under conditions advantageous for reproductive studies. The basic method of fertility testing has been recently described (Ericsson \& Baker, 1970). Only males which had mated at least once were used in libido and/or fertility studies. Epididymal lesions were identified by gross and histological observations of spermatocoeles in the ductuli efferentes and the caput region. Testes and epididymides were fixed in Bouin's fluid and stained with haematoxylin alone or counterstained with eosin. U-5897 was given orally in $0.25 \%$ methylcellulose in sterile $\mathrm{H}_{2} \mathrm{O}$.

\section{$U-5897$ stability}

A stock solution of U-5897 (50 mg/ml in $0.25 \%$ methylcellulose) was stored at room temperature for 1 year. This solution was diluted so that for assay, three male rats each received $5.0 \mathrm{mg}$ in $0.5 \mathrm{ml}$ orally for 8 days (see Ericsson \& Baker, 1970, for details). The stability in Lollipups dog food is referred to below. 
After storage in a sealed container at room temperature for 3 to 6 months, this food was fed to male rats in place of their regular diet. Males were checked for epididymal lesions 3 days later.

\section{Epididymal lesion dose}

Male rats were dosed orally with 30 and $35 \mathrm{mg} / \mathrm{kg}$ of U-5897 for 8 days and $30,35,45,60$ and $90 \mathrm{mg} / \mathrm{kg}$ once. They were killed 2 to 9 days after the first dose and checked for epididymal lesions. To establish the site and cause of the lesions, males were treated orally with one $30 \mathrm{mg} / \mathrm{rat}$ dose of U-5897 and killed on the 5th day after treatment. The ductuli efferentes and caput epididymidis were fixed intact and then sectioned in an attempt to locate the lesion.

\section{Fertility and libido}

Three groups of three rats were given one, two, or three 90 to $100 \mathrm{mg} / \mathrm{kg}$ oral doses $(30 \mathrm{mg} / \mathrm{rat})$ of U-5897. Two additional groups received eight daily oral doses of 10 and $15 \mathrm{mg} / \mathrm{rat}$ of U-5897. The control group consisted of three untreated males. One rat from each of the treated groups was killed on the 10th day after initiating treatment. Epididymides were checked for lesions and testes and epididymides saved for histological examination. Males were mated on the 8th or 9th day and once weekly thereafter. The experiment was stopped after 9 weeks and the males checked for epididymal lesions. The duration of sterility was tested after one or two oral doses $(90$ to $100 \mathrm{mg} / \mathrm{kg}$ ) at $3,6,9$, or 12 months after treatment. Each group, of varying numbers, was killed after mating and the testes and epididymides examined histologically.

\section{Compound acceptance}

Two groups of three males each $(325 \pm 25 \mathrm{~g})$ received U-5897 in their drinking water ( $10 \mathrm{mg}$ and $30 \mathrm{mg} / 80 \mathrm{ml}$, respectively), daily for 8 days. It had previously been established that rats of this weight drink 30 to $40 \mathrm{ml}$ of water $/ 24 \mathrm{hr}$. These males were then mated and checked for epididymal lesions.

A series of experiments was done with commercial dog foods to test the acceptability of U-5897. Top Choice (General Foods Corporation) was moistened and shaped into cubes weighing an average of $6 \mathrm{~g}$ each by the addition of $35 \mathrm{mg}$ of U-5897 in $0.8 \mathrm{ml}$ water/cube. Rats were taken off food 1 day before the experiment and were divided into groups receiving: (1) two control cubes, (2) two treated cubes, (3) one control and one treated cube. The day after feeding, the remaining food was weighed and the rats were returned to their normal diet.

The same procedure was used as in the above experiment except that the amount of food given each rat was doubled. Thus, the animals in one group were given four control cubes weighing approximately $6 \mathrm{~g} / \mathrm{cube}$, while a second group received control and treated cubes (12 mg U-5897/cube).

Lollipups dog food (Orleans Dog Candy Company) was also used as the compound vehicle. Control and treated cubes were prepared by immersion in $70 \%$ ethyl alcohol for $5 \mathrm{~min}$, the treated solution containing $10 \mathrm{mg} \mathrm{U}-5897 / \mathrm{ml}$. Treated cubes were prepared to contain either $8 \mathrm{mg}$ or $9 \mathrm{mg}$ of U-5897 each. The food was dried for $1 \mathrm{hr}$ at $70^{\circ} \mathrm{C}$ to evaporate the alcohol. Each animal was 
given ten cubes (five control and five treated) for a total of $22.25 \mathrm{~g}$ food/rat, or, in a separate experiment, three to five treated cubes only. As in the previous experiments, treatment was for 1 night only and the remaining food was weighed on the following day. Males in the above experiments were killed 3 to 6 days after feeding and examined for epididymal lesions.

\section{RESULTS}

No change in U-5897 antifertility potency was observed when the stock solution was tested 2, 8 and 12 months later. The nine rats, dosed at near the minimal effective dose, mated and were infertile. Dose titrations to find the level producing epididymal lesions are shown in Table 1. Lower repeated doses or a

\section{TABLE 1}

AMOUNT OF U-5897, MULTIPLE AND SINGLE DOSE, NEEDED TO PRODUCE EPIDIDYMAL LESIONS IN THE RAT

\begin{tabular}{l|c|c|c}
\hline $\begin{array}{c}\text { Oral } \\
\text { treatment }\end{array}$ & No. of rats & Av. score*/rat & $\begin{array}{c}\text { \% epididymides } \\
\text { with lesions }\end{array}$ \\
\cline { 2 - 3 } $30 \mathrm{mg} / \mathrm{kg}$ for 8 days & 10 & $1 \cdot 70$ & 45 \\
$35 \mathrm{mg} / \mathrm{kg}$ for 8 days & 10 & $2 \cdot 70$ & 70 \\
$30 \mathrm{mg} / \mathrm{kg}$ once & 10 & $0 \cdot 40$ & 10 \\
$35 \mathrm{mg} / \mathrm{kg}$ once & 31 & 1.46 & 37 \\
$45 \mathrm{mg} / \mathrm{kg}$ once & 68 & $3 \cdot 15$ & 80 \\
$60 \mathrm{mg} / \mathrm{kg}$ once & 10 & $4 \cdot 00$ & 100 \\
$90 \mathrm{mg} / \mathrm{kg}$ once & 19 & 4.00 & 100 \\
\hline
\end{tabular}

* Average score -0 for no lesion; 1 for partial blockage of efferents; 2 for complete lesion in caput $(\times 2 /$ rat $)$.

higher single dose will produce approximately the same percentage of epididymal lesions. A dose exists at which all rats will develop lesions (Table 1) without toxicity to general health. Doses lower than the $100 \%$ effective level can, on occasion, induce a unilateral lesion only.

The lesion occurs in the initial segment of the caput epididymidis (Pl. 1, Fig. 1), in which the lining epithelium detaches and blocks the caput (Pl. 1, Fig. 2). Gross observation of the lesion at 3 days shows sperm accumulation in proximal regions of the caput and vasa efferentia. Later observations show, in

\section{EXPLANATION OF PLATE 1}

Frg. 1. Swollen testis and spermatozoa accumulated in initial segment of the caput and vasa efferentia 1 day after 5-day treatment. Control testis on the left. $\times 1.5$.

FIG. 2. Initial segment of caput epididymidis 5 days after single treatment. The lining epithelium has detached and, together with spermatozoa and polymorphonuclear leucocytes, blocks the lumen. $\times 400$.

FIG. 3. Seminiferous tubule 2 days after 8-day treatment. Germinal elements in various stages of degeneration due to increased fluid pressure. $\times 400$.

Fig. 4. Sperm granuloma in initial segment of caput 2 days after 8 -day treatment. $\times 400$. FIG. 5. Seminiferous tubule 9 months after single lesion-producing dose. Most tubules inactive with only a few showing active spermatogenesis. $\times 400$.

Fig. 6. Lesion site in initial segment of caput 1 week after 8-day treatment. Fibrotic tissue has replaced other cells and the lumen. $\times 400$. 


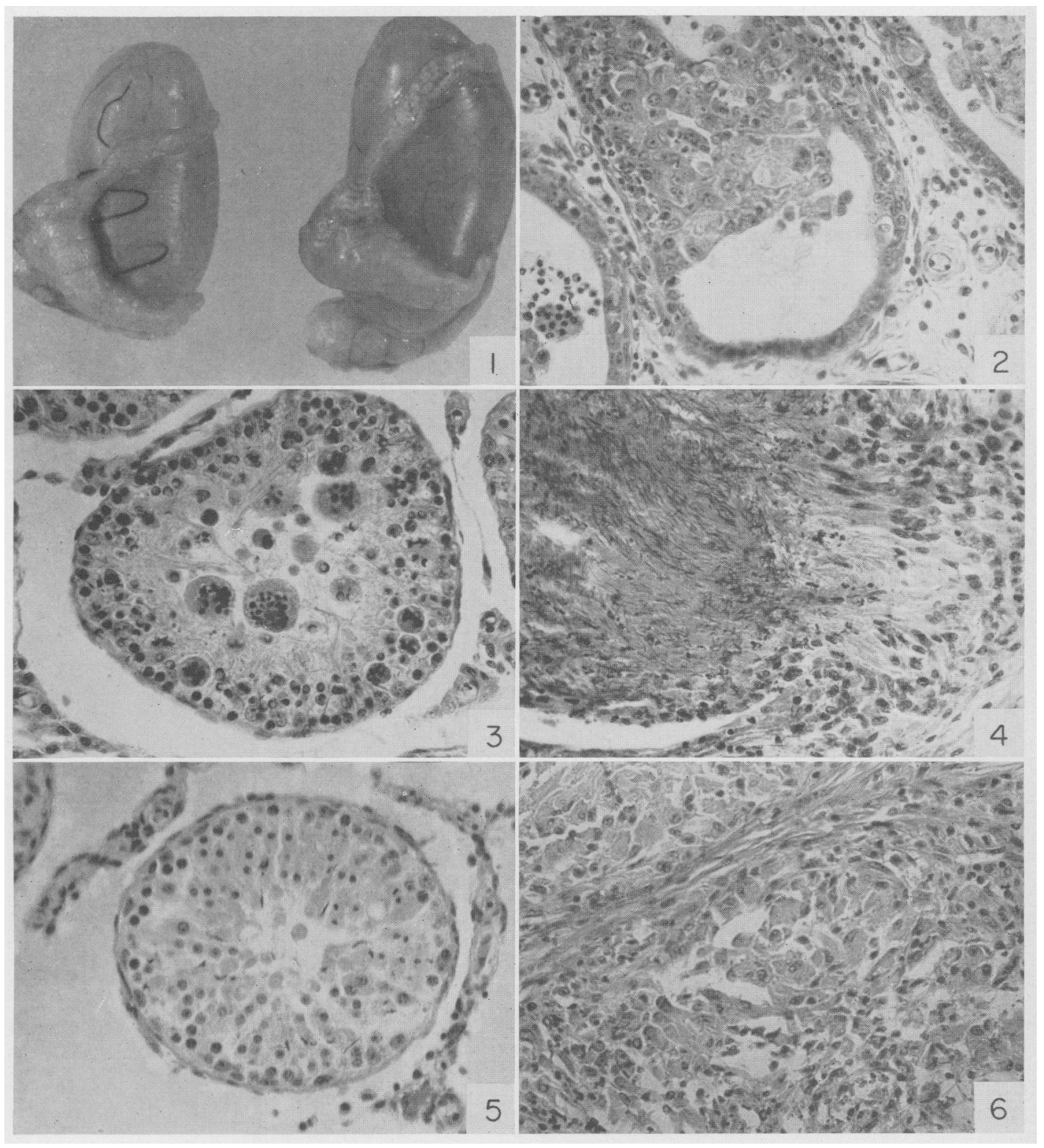

(Facing p. 216) 
TABLE 2

FERTILITY OF MALE RATS TREATED ORALLY WITH SINGLE OR MULTIPLE DOSES OF U-5897

\begin{tabular}{|c|c|c|c|c|c|c|c|c|c|}
\hline \multirow{2}{*}{$\begin{array}{l}\text { Dose/rat* } \\
\text { and days } \\
\text { tested }\end{array}$} & \multirow{2}{*}{$\begin{array}{l}\text { Rat } \\
\text { no. }\end{array}$} & \multicolumn{8}{|c|}{ Weeks } \\
\hline & & 1 & 2 & 3 & 4 & 5 & 6 & 7 & 8 \\
\hline $\begin{array}{l}30 \mathrm{mg} \\
\text { (1 day) }\end{array}$ & $\begin{array}{l}1 \\
2 \\
3\end{array}$ & $\begin{array}{l}\text { SP-9† } \\
\text { SP-13 } \\
\text { SP-0 }\end{array}$ & $\begin{array}{l}\text { killed } \\
\text { SP-12 } \\
\text { SP-0 }\end{array}$ & $\begin{array}{l}\mathrm{P}-0 \\
\mathrm{P}-0\end{array}$ & $\begin{array}{l}\mathrm{P}-0 \\
\mathrm{P}-0\end{array}$ & $\begin{array}{l}\mathrm{P}-0 \\
\mathrm{P}-0\end{array}$ & $\begin{array}{l}\mathrm{P}-0 \\
\mathrm{P}-0\end{array}$ & $\begin{array}{l}\mathrm{X}-0 \\
\mathrm{P}-0\end{array}$ & $\begin{array}{l}\mathrm{P}-0 \\
\mathrm{P}-0\end{array}$ \\
\hline $\begin{array}{l}30 \mathrm{mg} \\
\text { (2 days) }\end{array}$ & $\begin{array}{l}1 \\
2 \\
3\end{array}$ & $\begin{array}{l}\mathrm{SP}-0 \\
\mathrm{SP}-0 \\
\mathrm{SP}-0\end{array}$ & $\begin{array}{l}\text { killed } \\
\mathrm{SP}-0 \\
\mathrm{SP}-0\end{array}$ & $\begin{array}{l}\mathrm{X}-0 \\
\mathrm{P}-0\end{array}$ & $\begin{array}{l}\mathbf{P}-\mathbf{0} \\
\mathbf{P}-0\end{array}$ & $\begin{array}{l}\mathrm{P}-0 \\
\mathrm{P}-0\end{array}$ & $\begin{array}{l}\mathbf{P}-0 \\
\mathbf{P}-0\end{array}$ & $\begin{array}{r}\mathrm{P}-0 \\
\mathrm{X}-0\end{array}$ & $\begin{array}{l}\mathrm{P}-0 \\
\mathrm{X}-0\end{array}$ \\
\hline $\begin{array}{l}30 \mathrm{mg} \\
\text { (3 days) }\end{array}$ & $\begin{array}{l}1 \\
2 \\
3\end{array}$ & $\begin{array}{c}\mathrm{SP}-0 \\
\mathrm{SP}-0 \\
\text { died }\end{array}$ & $\begin{array}{l}\text { killed } \\
\mathrm{SP}-0\end{array}$ & $\mathrm{P}-0$ & $\mathbf{P}-0$ & $\mathbf{P}-0$ & $P-0$ & $P-0$ & $\mathbf{P}-0$ \\
\hline $\begin{array}{l}10 \mathrm{mg} \\
\text { (8 days) }\end{array}$ & $\begin{array}{l}1 \\
2 \\
3\end{array}$ & $\begin{array}{l}\mathrm{SP}-0 \\
\mathrm{SP}-1 \\
\mathrm{SP}-2\end{array}$ & $\begin{array}{r}\mathrm{SP}-0 \\
\text { killed }\end{array}$ & $\begin{array}{l}\mathbf{S P}-0 \\
\mathbf{S P}-0\end{array}$ & $\begin{array}{l}\mathrm{SP}-0 \\
\mathrm{SP}-0\end{array}$ & $\begin{array}{r}\mathbf{P}-0 \\
\mathrm{X}-0\end{array}$ & $\begin{array}{l}\mathrm{P}-0 \\
\mathrm{P}-0\end{array}$ & $\begin{array}{l}\mathbf{P}-0 \\
\mathbf{P}-0\end{array}$ & $\begin{array}{l}P-0 \\
P-0\end{array}$ \\
\hline $\begin{array}{l}15 \mathrm{mg} \\
\text { (8 days) }\end{array}$ & $\begin{array}{l}1 \\
2 \\
3\end{array}$ & $\begin{array}{l}\mathrm{SP}-0 \\
\mathrm{SP}-0 \\
\mathrm{SP}-0\end{array}$ & $\begin{array}{l}\text { killed } \\
\mathrm{SP}-0 \\
\mathrm{SP}-0\end{array}$ & $\begin{array}{l}\mathrm{P}-0 \\
\mathrm{P}-0\end{array}$ & $\begin{array}{l}\mathbf{P}-0 \\
\mathbf{P}-0\end{array}$ & $\begin{array}{l}\mathrm{P}-0 \\
\mathrm{P}-0\end{array}$ & $\begin{array}{l}\mathrm{P}-0 \\
\mathrm{P}-0\end{array}$ & $\begin{array}{l}\mathrm{P}-0 \\
\mathrm{P}-0\end{array}$ & $\begin{array}{l}\mathrm{P}-\mathbf{0} \\
\mathrm{P}-\mathbf{0}\end{array}$ \\
\hline Control & $\begin{array}{l}1 \\
2 \\
3\end{array}$ & & & & $\begin{array}{l}\mathrm{SP}-13 \\
\mathrm{SP}-11 \\
\mathrm{SP}-13\end{array}$ & $\begin{array}{c}\mathbf{P}-13 \\
\mathrm{X}-14\end{array}$ & $\begin{array}{l}\mathrm{SP}-12 \\
\mathrm{SP}-0 \\
\mathrm{SP}-8\end{array}$ & $\begin{array}{l}S P-10 \\
S P-14 \\
S P-15\end{array}$ & $\begin{array}{l}\text { SP-10 } \\
\text { SP-6 } \\
\text { SP-0 }\end{array}$ \\
\hline
\end{tabular}

Rat weight $325 \pm 25 \mathrm{~g}$.

$\dagger$ Evidence for mating is provided by the terms SP (spermatozoa and vaginal plug), $\mathbf{P}$ (vaginal plug only), and $X$ (no evidence of mating). The corresponding numerals in each square refer to the number of implantation sites.

TABLE 3

REPRODUCTIVE CONDITION OF U-5897-TREATED RATS 64 DAYS AFTER INITIAL TREATMENT

\begin{tabular}{|c|c|c|c|c|c|c|}
\hline $\begin{array}{c}\text { Dose/rat } \\
\text { and days } \\
\text { treated }\end{array}$ & $\begin{array}{l}\text { Rat } \\
\text { no. }\end{array}$ & $\begin{array}{c}\text { Body } \\
w t(g)\end{array}$ & $\begin{array}{c}\text { Epididymal } \\
\text { wt }(g)\end{array}$ & $\begin{array}{c}\text { Testicular } \\
w t(g)\end{array}$ & $\begin{array}{c}\text { Epididymal } \\
\text { lesions }\end{array}$ & $\begin{array}{l}\text { Sperm* } \\
\text { granuloma }\end{array}$ \\
\hline $\begin{array}{l}30 \mathrm{mg} \\
\text { (1 day) }\end{array}$ & $\begin{array}{l}2 \\
3\end{array}$ & $\begin{array}{l}452 \\
498\end{array}$ & $\begin{array}{l}0.70 \\
0.63\end{array}$ & $\begin{array}{l}1 \cdot 99 \\
2 \cdot 38\end{array}$ & $\begin{array}{l}\text { Yes } \\
\text { Yes }\end{array}$ & $\begin{array}{l}\text { No } \\
\text { No }\end{array}$ \\
\hline $\begin{array}{l}30 \text { mg } \\
\text { ( } 2 \text { days) }\end{array}$ & $\begin{array}{l}2 \\
3\end{array}$ & $\begin{array}{l}462 \\
379\end{array}$ & $\begin{array}{l}0.82 \\
0.70\end{array}$ & $\begin{array}{l}2 \cdot 57 \\
2 \cdot 28\end{array}$ & $\begin{array}{l}\text { Yes } \\
\text { Yes }\end{array}$ & $\begin{array}{l}\text { No } \\
\text { No }\end{array}$ \\
\hline $\begin{array}{l}30 \mathrm{mg} \\
\text { (3 days) }\end{array}$ & 2 & 461 & 0.65 & $2 \cdot 45$ & Yes & Yes \\
\hline $\begin{array}{l}10 \mathrm{mg} \\
\text { (8 days) }\end{array}$ & $\begin{array}{l}1 \\
2\end{array}$ & $\begin{array}{l}502 \\
478\end{array}$ & $\begin{array}{l}0.78 \\
0.70\end{array}$ & $\begin{array}{l}2 \cdot 25 \\
2 \cdot 08\end{array}$ & $\begin{array}{l}\text { Yes } \\
\text { Yes }\end{array}$ & $\begin{array}{l}\text { Yes } \\
\text { Yes }\end{array}$ \\
\hline $\begin{array}{l}15 \mathrm{mg} \\
\text { (8 days) }\end{array}$ & $\begin{array}{l}2 \\
3\end{array}$ & $\begin{array}{l}490 \\
486\end{array}$ & $\begin{array}{l}0.79 \\
0.73\end{array}$ & $\begin{array}{l}2 \cdot 28 \\
2 \cdot 46\end{array}$ & $\begin{array}{l}\text { Yes } \\
\text { Yes }\end{array}$ & $\begin{array}{l}\text { Yes } \\
\text { Yes }\end{array}$ \\
\hline Control & $\begin{array}{l}1 \\
2 \\
3\end{array}$ & $\begin{array}{l}416 \\
393 \\
458\end{array}$ & $\begin{array}{l}1 \cdot 30 \\
1 \cdot 33 \\
1 \cdot 28\end{array}$ & $\begin{array}{l}4 \cdot 01 \\
4 \cdot 03 \\
3 \cdot 79\end{array}$ & $\begin{array}{l}\text { No } \\
\text { No } \\
\text { No }\end{array}$ & $\begin{array}{l}\text { No } \\
\text { No } \\
\text { No }\end{array}$ \\
\hline
\end{tabular}

* Spermatozoa found in interstitium due to ruptured efferent or epididymal ducts. 
addition to spermatocoeles, sperm granulomata and spermatozoa trapped in the testes. The lesion prevents adequate removal of testicular fluid and within

Table 4

PERMANENCE OF STERILITY AND LIBIDO OF MALE RATS TREATED ORALLY WITH U-5897

\begin{tabular}{|c|c|c|c|c|c|c|c|}
\hline $\begin{array}{c}\text { Oral treatment } \\
(90 \mathrm{to} 100 \\
\mathrm{mg} / \mathrm{kg})\end{array}$ & Rat no. & $\begin{array}{c}\text { Months } \\
\text { post-treatment }\end{array}$ & Vaginal plug & Sperm. & $\begin{array}{c}\text { No. of } \\
\text { implants }\end{array}$ & $\begin{array}{l}\text { Final body } \\
\text { wt }(\mathrm{g})\end{array}$ & $\begin{array}{c}\text { Testicular } \\
w t(g)\end{array}$ \\
\hline Two doses & $\begin{array}{l}1 \\
2 \\
3\end{array}$ & 3 & $\begin{array}{l}\stackrel{+}{\mathrm{DNM}} \\
+\end{array}$ & E & $\begin{array}{l}0 \\
0\end{array}$ & $\begin{array}{l}504 \\
547 \\
432\end{array}$ & - \\
\hline One dose & $\begin{array}{l}1 \\
2 \\
3 \\
4\end{array}$ & 3 & $\begin{array}{c}+ \\
+ \\
+ \\
\mathrm{DNM}\end{array}$ & 二 & $\begin{array}{l}0 \\
0 \\
0\end{array}$ & $\begin{array}{l}510 \\
532 \\
464 \\
444\end{array}$ & $\begin{array}{l}2 \cdot 55 \\
2 \cdot 88 \\
1 \cdot 83 \\
2 \cdot 56\end{array}$ \\
\hline One dose & $\begin{array}{l}1 \\
2 \\
3 \\
4 \\
5 \\
6 \\
7\end{array}$ & 6 & $\begin{array}{c}\text { DNM } \\
+ \\
+ \\
+ \\
\text { DNM } \\
+ \\
+\end{array}$ & $\begin{array}{l}\text { few } \\
= \\
= \\
=\end{array}$ & $\begin{array}{l}0 \\
0 \\
0 \\
0 \\
\\
0 \\
0\end{array}$ & $\begin{array}{l}590 \\
505 \\
510 \\
550 \\
555 \\
570 \\
590\end{array}$ & $\begin{array}{l}1.75 \\
0.84 \\
1.50 \\
2.17 \\
2.09 \\
2.09 \\
1.87\end{array}$ \\
\hline One dose & $\begin{array}{l}1 \\
2 \\
3 \\
4 \\
5\end{array}$ & 9 & $\begin{array}{c}+ \\
\stackrel{+}{+} \\
\text { DNM } \\
\text { DNM } \\
\text { DNM }\end{array}$ & - & $\begin{array}{l}0 \\
0\end{array}$ & $\begin{array}{l}640 \\
660 \\
450 \\
380 \\
540\end{array}$ & $\begin{array}{l}1.98 \\
1.49 \\
1.68 \\
0.85 \\
2.31\end{array}$ \\
\hline One dose & 1 & 12 & + & - & 0 & 650 & 1.37 \\
\hline
\end{tabular}

DNM $=$ did not mate when given two opportunities with oestrous females.

TABLE 5

ABILITY OF U-5897 TO PRODUCE EPIDIDYMAL LESIONS WHEN MIXED WITH TOP GHOIGE DOG FOOD

\begin{tabular}{l|c|c|c|c|c}
\hline \multicolumn{1}{c|}{ Groups } & $\begin{array}{c}\text { No. of 6-g } \\
\text { cubes }\end{array}$ & $\begin{array}{c}\text { No. of } \\
\text { rats }\end{array}$ & $\begin{array}{c}\text { Av. body wt } \\
(\mathrm{g})\end{array}$ & $\begin{array}{c}\text { Av. amount } \\
\text { of food } \\
\text { consumed }(\mathrm{g})\end{array}$ & $\begin{array}{c}\% \text { epididymides } \\
\text { with lesions }\end{array}$ \\
\hline $\begin{array}{l}\text { Control } \\
\begin{array}{l}\text { Control + treated } \\
(35 \mathrm{mg} / \text { cube })\end{array}\end{array}$ & $\begin{array}{c}2 \\
\text { of each }\end{array}$ & 10 & 430 & $12 \cdot 0$ & 0 \\
$\begin{array}{l}\text { Treated } \\
(35 \mathrm{mg} / \text { cube })\end{array}$ & 2 & 10 & 328 & $10 \cdot 3$ & 100 \\
\hline $\begin{array}{l}\text { Control } \\
\begin{array}{l}\text { Control+treated } \\
(12 \mathrm{mg} / \text { cube })\end{array}\end{array}$ & 2 of each & 7 & 44 & $7 \cdot 5$ & 80 \\
\hline
\end{tabular}

2 days, causes testicular swelling which inhibits spermatogenesis through pressure degeneration of the germinal epithelium (Pl. 1, Fig. 3). Granulomata occur when pressures in the extragonadal ducts become too great and spermatozoa 
pass through the ruptured epididymal ducts into the interstitium (P1. 1, Fig. 4). Permanence of the lesion depends on the severity of epithelial necrosis and on fibrosis of the tissue. Males killed at 3- to 12-month intervals after treatment

TABLE 6

ABILITY OF U-5897 TO PRODUCE EPIDIDYMAL LESIONS WHEN MIXED WITH LOLLIPUPS DOG FOOD AT 8 OR 9 MG/GUBE

\begin{tabular}{|c|c|c|c|c|c|}
\hline $\begin{array}{l}\text { No. of cubes } \\
\text { consumed } \\
\text { pre-treatment }\end{array}$ & No. of cubes & $\begin{array}{c}\text { Total weight } \\
\text { of Lollipups } \\
(\mathrm{g})\end{array}$ & Rat no. & $\begin{array}{c}\text { Food } \\
\text { consumed }(g)\end{array}$ & $\begin{array}{c}\text { Epididymal } \\
\text { lesions }\end{array}$ \\
\hline (1 day) & $\begin{array}{l}5 \text { treated }+ \\
5 \text { untreated } \\
\text { Lollipups }\end{array}$ & $22 \cdot 3$ & $\begin{array}{l}1 \\
2 \\
3 \\
4\end{array}$ & $\begin{array}{l}13 \cdot 9 \\
11 \cdot 1 \\
16 \cdot 0 \\
20 \cdot 0\end{array}$ & $\begin{array}{l}\text { No } \\
\text { Yes } \\
\text { Yes } \\
\text { Yes }\end{array}$ \\
\hline \multirow{3}{*}{$\begin{array}{c}20 \\
\text { (10 each day) }\end{array}$} & \multirow{3}{*}{$\begin{array}{l}5 \text { treated } \\
\text { Lollipups }+ \\
5 \text { cubes } \\
\text { Purina rat } \\
\text { chow }\end{array}$} & \multirow[t]{3}{*}{11.3} & 1 & $4 \cdot 4$ & Yes \\
\hline & & & 2 & $4 \cdot 6$ & Yes* \\
\hline & & & 3 & $8 \cdot 9$ & Yes \\
\hline $\begin{array}{l}\text { No pre-treat- } \\
\text { ment }\end{array}$ & $\begin{array}{l}3 \text { treated } \\
3 \text { treated } \\
4 \text { treated } \\
4 \text { treated } \\
5 \text { treated } \\
5 \text { treated }\end{array}$ & $\begin{array}{r}7 \cdot 5 \\
7 \cdot 5 \\
10 \cdot 0 \\
10 \cdot 0 \\
12 \cdot 5 \\
12 \cdot 5\end{array}$ & $\begin{array}{l}1 \\
2 \\
3 \\
4 \\
5 \\
6\end{array}$ & $\begin{array}{l}6.9(65.2) \dagger \\
7.3(73.4) \\
7.0(75 \cdot 6) \\
5.4(48.5) \\
4.2(62.9) \\
3.9(58.5)\end{array}$ & $\begin{array}{l}\text { Yes } \\
\text { Yes } \\
\text { Yes } \\
\text { Yes } \\
\text { Yes } \\
\text { Yes }\end{array}$ \\
\hline
\end{tabular}

* On one side only.

† mg U-5897/kg consumed.

TABLE 7

POTENCY OF U-5897 AS A CHEMOSTERILANT AFTER BEING IN FOOD FOR 3 AND 6 MONTHS

\begin{tabular}{|c|c|c|c|c|c|c|}
\hline Treatment & $\begin{array}{l}\text { No. of } \\
\text { rats }\end{array}$ & $\begin{array}{l}\text { Av. body } \\
\text { wt }(g)\end{array}$ & $\begin{array}{c}M g \\
U-5897 \\
\text { consumed }\end{array}$ & $\begin{array}{c}U-5897 \\
A v . \\
m g / k g\end{array}$ & $\begin{array}{c}\text { Av. score* } \\
\text { |rat }\end{array}$ & $\begin{array}{c}\% \\
\text { epididymides } \\
\text { with lesions }\end{array}$ \\
\hline $\begin{array}{l}8 \mathrm{mg} / 2 \cdot 25 \mathrm{~g} \text { cube after } \\
3 \mathrm{months}(2 \text { to } 7 \text { cubes } / \mathrm{rat})\end{array}$ & 6 & 385 & 16 to 32 & - & $4 \cdot 00$ & 100 \\
\hline $\begin{array}{l}8 \mathrm{mg} / 2 \cdot 25 \mathrm{~g} \text { cube after } \\
6 \text { months }(2 \text { cubes } / \mathrm{rat})\end{array}$ & 15 & 320 & 14.9 Av. & $46 \cdot 4$ & $2 \cdot 40$ & 67 \\
\hline $\begin{array}{l}9 \mathrm{mg} / 2 \cdot 50 \mathrm{~g} \text { cube after } \\
0 \text { months }(2 \text { cubes } / \mathrm{rat})\end{array}$ & 10 & 356 & 17.5 Av. & $49 \cdot 1$ & $2 \cdot 83$ & 75 \\
\hline $\begin{array}{l}2.25 \mathrm{~g} \text { and } 2.50 \mathrm{~g} \text { control } \\
\text { cubes }\end{array}$ & 10 & 336 & $\begin{array}{l}\text { consumed } \\
\text { all food }\end{array}$ & - & 0.0 & 0 \\
\hline
\end{tabular}

* See Table 1 for explanation.

had small testes with a few groups of active seminiferous tubules (Pl. 1, Fig. 5). Leydig cells appeared normal and seemed to function adequately, supporting some spermatogenesis, good libido, and vaginal plug formation on mating. Epididymides taken from U-5897-treated rats looked normal except for the absence of spermatozoa and the presence of fibrotic tissue at the site of the lesion (Pl. 1, Fig. 6). 
The fertility of males given lesion-inducing doses of U-5897 became impaired during the 1st week and subsequently culminated in sterility (Table 2), but the libido of these males was unchanged with seventy-one matings out of seventyseven opportunities $(92 \%)$. All males had bilateral epididymal lesions when checked 64 days after initial treatment. Weight loss occurred in testes and epididymides but body growth was normal (Table 3). In a further study (Table 4), all males which were found to be sterile remained so over 12 months due to epididymal lesions. The libido of these males, as measured by ability and desire to mate, was good.

Epididymal lesions in one of three animals followed administration of the compound for 8 days in the drinking water at a concentration of $10 \mathrm{mg} / 80 \mathrm{ml}$ and in two of three animals at a concentration of $30 \mathrm{mg} / 80 \mathrm{ml}$. Average daily consumption of water was $48 \mathrm{ml}$ and $31 \mathrm{ml}$, respectively. Three of the six males mated and were infertile.

Rats will also consume U-5897 when mixed in the food. The control food was preferred, but when given a choice, they still ate enough food with U-5897 to develop lesions (Tables 5 and 6). Food from the second compound acceptance study (Table 6) was saved for 6 months and retested. No deterioration in chemosterilant potency was seen in food kept for 6 months (Table 7).

\section{DISCUSSION}

The fact that U-5897 produces temporary or permanent sterility in the male rat, only temporary sterility in the guinea-pig and monkey (Ericsson \& Baker, 1970; Kirton et al., 1970) and is without action in mouse and rabbit (unpublished data) presents the scientist with a multi-faceted enigma. Multiple oral doses are required to produce reversible sterility in the rat while a single higher dose suffices for permanent sterility. The irony of U-5897 is this dichotomy. The remarkable action of this compound can also serve as a new tool for fundamental studies on sperm maturation in the epididymis.

Lesions of the rat caput epididymidis develop if the superior epididymal branch and accessory capital arteries are ligated (Macmillan, 1953), or if cadmium is administered (Mason \& Young, 1967). It is suggested that the cadmium ion affects either the testicular vessels and their epididymal branches (Gunn, Gould, \& Anderson, 1963), or their end-arterial capillary bed (Mason, Brown, Young \& Nesbit, 1964). The number of rats with lesions following either cadmium administration or ligation of superior epididymal vessels (but not small capital branches of the inferior epididymal vessels) approaches $30 \%$. Only when both branches of arterial vessels to the caput are blocked, do all rats develop lesions. The initial segment of the caput epididymidis is particularly vulnerable to sudden alterations in its blood supply (Macmillan, 1956). Although this region of the epididymis has the highest venous blood flow, it also has high metabolic activity (Setchell, Waites \& Till, 1964). Blood flow through the epididymal branches which supply this region of the epididymis is presumed to be sluggish (Mason et al., 1964). If U-5897 operates by way of the vascular system, one might first consider the epididymal branches of the testicular artery. The vulnerability of the caput plus the slow blood flow seem con- 
ducive to a chemical change in vascular permeability. U-5897 may, therefore, produce a local ischaemia in the initial segment region, for epididymal lesions produced by ligation of $\mathrm{U}-5897$ are identical in time of formation, location, type and final disposition.

Capillaries of the initial segment, unlike other epididymal regions, are loosely located in the inter-ductular tissue and not intimately related to the basement membrane (Kormano, 1968). Changes in the end-arterial capillary bed could be the site of U-5897 action. Cadmium, as suggested by Mason et al. (1964), may act upon this area. U-5897, at the proper dose, in contrast to cadmium, will consistently produce lesions in all mature rats. Further differences are that the chlorohydrin produces a reversible post-testicular antifertility effect at low doses and at no dose does it seem to have a direct effect on the testis. If the two compounds act by the same mechanism, then U-5897 is more effective in developing epididymal lesions.

The beauty of U-5897 as a male chemosterilant is expressed in the simplicity of its application and efficacy of its sterilant action following a single oral dose. U-5897 fulfils most major requirements for a practical male rat chemosterilant and needs now to be tested in the field. In practical terms, the wild Rattus norvegicus should develop sterility upon consuming 15 to $40 \mathrm{mg}$ of U-5897.

Lack of enthusiasm over male antispermatogenic chemosterilants has been expressed because of potential loss of libido and aggressiveness (Howard, 1967). This seems of no concern in rats treated with a sterilizing dose of U-5897, since libido was shown to be normal. All parameters showed that Leydig cells from treated males were not detrimentally affected. Impairment of spermatogenesis is due to pressure necrosis and is, therefore, indirect.

A discussion of the application of U-5897 in wild rat population control is beyond the scope of this publication. As with any control agent, ecological factors following its use will arise. The behavioural response to limiting the number of offspring is unknown, as are the results of the drastic reduction in male population to challenge for social position and territorial rights. Maybe maternal behaviour, fecundity, male aggression and gregariousness will undergo dramatic changes.

\section{ACKNOWLEDGMENTS}

Dr G. W. Duncan receives thanks for provoking the author to investigate U-5897 as a chemosterilant. The fine technical assistance of A. J. Balcuns, J. F. Norland and K. K. Bergstrom is appreciated.

\section{REFERENCES}

Bentley, E. W. (1967) The control of rodents. WHO Chron. 21, 363.

Gilinton, J. M, (1968) Rats and the urban scene. Ann. intern. Med. 69, 839.

ERIcsson, R. J. \& BAKer, V. F. (1970) Male antifertility compounds: biological properties of U-5897 and U-15,646. F. Reprod. Fert. 21, 267.

Ericsson, R. J. \& Youngdale, G. A. (1970) Male antifertility compounds: structure and activity relationships of U-5897, U-15,646 and related substances. 7. Reprod. Fert. 21, 263.

Gunn, S. A., Gould, T. C. \& Anderson, W. A. D. (1963) The selective injurious response of testicular and epididymal blood vessels to cadmium and its prevention by zinc. Am. 7. Path. 42, 685 .

Howard, W. E. (1967) Biocontrol and chemosterilants. In: Pest Control. Eds. W. W. Kilgore and R. L. Doutt. Academic Press, New York. 
Kirton, K. T., Ericsson, R. J., Millek, W. L., Cornetre, J. C., Forbes, A. D. \& Duncan, G. W. (1969) Mechanism studies with male antifertility compound U-5897 $\left({ }^{14} \mathrm{C}\right.$-labeled 3-chloro-1,2propanediol). (Abstract). Fedn Proc. Fedn Am. Socs exp. Biol. 28, 705.

Kirton, K. T., ERIcsson, R. J., RAy, J. A. \& Forbes, A. D. (1970) Male antifertility compounds: efficacy of U-5897 in primates (Macaca mulatta). F. Reprod. Fert. 21, 275.

Knipling, E. F. (1959) Sterile-male method of population control. Science, N.Y. 130, 902.

Kormano, M. (1968) Microvascular structure of the rat epididymis. Annls Med. exp. Biol. Fenn. 46, 113.

Macmillan, E. W. (1953) Higher epididymal obstructions in male infertility. Fert. Steril. 4, 101.

Macmillan, E. W. (1956) The immediate effects of occlusion of superior epididymal arteries in the rat as demonstrated by the use of radiopaque medium. Proc. Soc. Study Fert. 8, 67.

Mason, K. E., Brown, J. A., Young, J. O. \& Nesbit, R. R. (1964) Cadmium-induced injury of the rat testis. Anat. Rec. 149, 135.

Mason, K. E. \& Young, J. O. (1967) Effects of cadmium upon the excurrent duct system of the rat testis. Anat. Rec. 159, 311.

Pool, J. G., O'Reilly, R. A., Schneiderman, L. J. \& Alexander, M. (1968) Warfarin resistance in the rat. Am. F. Physiol. 215, 627.

Setchell, B. P., Waites, G. M. H. \& Till, A. R. (1964) Variations in flow of blood within the epididymis and testis of the sheep and rat. Nature, Lond. 203, 317. 